\title{
The Role of Vaccination and Screening in Limiting the Worldwide Disease Burden of Preventable Female Cancers: A Review
}

\author{
Claudio Costantino*(D), Davide Alba, Livia Cimino, Arianna Conforto and Walter Mazzucco $\mathbb{D}$ \\ Department of Health Promotion, Maternal and Infant Care, Internal Medicine and Excellence \\ Specialties (PROMISE), University of Palermo, Via del Vespro, 133, 90127 Palermo, Italy; \\ davide.alba@unipa.it (D.A.); livia.cimino@unipa.it (L.C.); arianna.conforto@unipa.it (A.C.); \\ walter.mazzucco@unipa.it (W.M.) \\ * Correspondence: claudio.costantino01@unipa.it
}

Received: 10 August 2020; Accepted: 14 October 2020; Published: 19 October 2020

\begin{abstract}
Cancer represents one of the most common causes of death worldwide. Among women, breast cancer is the most diagnosed cancer and the principal cause of death due to malignant disease, while cervical cancer ranks fourth for both incidence and mortality. The present review aims to analyze the epidemiology of cervical and breast cancer (incidence, mortality, survival rates, and trends). Moreover, the most important primary and secondary preventive strategies (reduction of risk factors, exposure, vaccination, cancer screening) intended to reduce the future burden of cervical and breast cancer, that should be adopted actively and free of charge, were discussed in accordance to more recent and evidence-based findings.
\end{abstract}

Keywords: women; female cancer; cervical cancer; breast cancer; cancer screening; vaccination; prevention

\section{Background}

Worldwide, cancer represents one of the most common causes of death among women, both in high-income and middle-income countries [1].

Over the last decade, the cancer burden is expanding in countries with low income levels, whereas an increasing average of life expectancy, due to public health measures such as prevention of infectious diseases and reductions in maternal, infant, and childhood mortality, contribute to the growth and aging of the general population $[1,2]$.

Risk factors for female cancer can be classified in two main classes: cancer associated to exposures like men and those exposures and forms of cancer unique to women [1].

The economic transition with an exposure to new risk factors, such as smoking and sexual habits, excess body weight and physical inactivity, has been playing a major role in this increasing trend $[3,4]$. Due to these transitions, cancers that were previously common in high-income areas are becoming more prevalent also in low- and middle-income areas [5].

Moreover, changes in reproductive patterns, such as a later age at first childbirth and lower parity, have contributed to the higher female cancer burden worldwide [6]. In addition to the morbidity and mortality burdens, cancer diagnoses worldwide carry a considerable economic impact on health systems, including direct costs, mostly the ones related to treatment; and indirect costs, such as the ones charged to the families or the society according to loss of income or productivity [7].

Other quantifiable costs, such as time spent by caregivers, transportation, and assistance at home, could be associated with cancer diagnosis and treatment [8]. 
Furthermore, cancer burden and the associated incremental costs can also be related to the improvement in cancer survival both in high- and low-income countries [8,9]. In particular, patient survival rates vary across the different types of female cancers and are largely dependent on the stage at which a particular cancer is diagnosed [9].

For all these reasons, cancer prevention and early detection are necessary in high and low resource settings in order to limit the impact of this disease [10].

Primary prevention could prevent about one-third to half of cancer cases limiting the exposure to well-known risk factors [10]. Vaccinations, such as the ones against human papillomavirus (HPV) and hepatitis B, health education, prevention of smoking or drinking habits, positive lifestyles (such as healthy nutrition and/or physical activity) represent the basic preventive strategies in order to prevent cancers in both sexes [11].

Moreover, secondary prevention, such as cervical, breast, and colorectal cancer screening, can detect precancerous lesions or cancer at early stages $[12,13]$.

We review here the scientific literature to summarize the epidemiology and to highlight the most recent findings in primary and secondary prevention of cervical and breast cancers, two of the major public health issues related to cancers occurring among women.

\section{Epidemiology of Cervical Cancer}

Cervical cancer (CC) represents the fourth most common female cancer in the world, with more than 500,000 new cases and 300,000 deaths estimated yearly [14,15].

Incidence rates of CC are highest in women 35 to 44 years old, whereas the highest rates of ovarian or uterine cancer are documented in women aged 55 to 64 years (median age at diagnosis: 63 years) $[16,17]$. Of note, the median age at diagnosis of CC is 49 years [18]. While the highest incidence for CC was registered among Hispanics with approximately 10.9 new cases per 100,000 persons, 13.3 incidents per 100,000 ovarian cancer cases resulted more frequently in white women [19].

Over the past three decades, incidence of CC has halved, prominently due to HPV vaccination and progressive extension of Pap-test screening $[19,20]$.

Since 2006, the availability of three vaccines against the human papillomavirus (HPV) has allowed a reduction of HPV infections and will likely influence the burden of HPV-associated diseases, including CC $[21,22]$.

While incidence rates of uterine, vaginal, and vulvar cancers have remained relatively stable over the last decade, cervical cancer diagnoses have tended to occur earlier in the disease process due to adoption of secondary (cervical cancer screening) preventive strategies $[19,23]$.

The median age of deaths due to CC is 57 years, with specific mortality rates that are twice those among black women than white women [24].

Factors associated with an increased risk for CC include HPV infection, smoking, immunosuppression (either from human immunodeficiency virus infection or from immunosuppressive drugs), chlamydia infection, long-term use of oral contraceptives, reproductive history (number of pregnancies), younger age at first full-term pregnancy, high deprivation index and family history of CC [25,26].

$\mathrm{HPV}$ infection is recognized as the main risk factor for cervical cancer, accounting for more than $90 \%$ of all CC $[19,22,27]$. By contrast, use of intrauterine devices was associated with a decreased risk for CC [28].

\section{Epidemiology of Breast Cancer}

With over 2 million cases annually, breast cancer (BC) is the most common cancer diagnosed and one of the most significant causes of death among women [29,30]. Although this neoplasia occurs all over the world, incidence, mortality, and survival rates change considerably among different countries, relative to population structure, genetic factors, lifestyle, and environment [31]. 
BC incidence rates range from 27 per 100,000 in Central Africa and Eastern Asia to 92 per 100,000 in North America and around 100 per 100,000 in European countries, representing the fifth most common cause of death from cancer in women, with 522,000 deaths estimated every year [29].

The risk of $\mathrm{BC}$ doubles each decade until menopause (after which it slows) and diagnosis is generally more common after menopause.

Previous research conducted among women who migrated from areas of low risk (less developed countries) to areas of high risk (more developed countries) showed that they assume the host country incidence rate of $\mathrm{BC}$, within one or two generations, confirming the fundamental role of environment.

As a matter of fact, $\mathrm{BC}$ is a multifactorial disease and various factors contribute to its occurrence (such as a familial history of breast cancer, dietary effects combined with later first childbirth, lower parity, and shorter breastfeeding) [32].

Despite BC having been the subject of several epidemiological studies, the understanding of its aetiology remains under investigation and there are still some preventable factors missing and yet to be identified [30].

Hormones (both exogenous and endogenous) have a recognized role in BC risk among women and, specifically, oral contraceptives are associated with increased risk of $\mathrm{BC}$ in women up to 38 years old, even if they have a role in the prevention of ovarian and endometrial cancer [33].

Oestrogen therapy as hormonal replacement increased the risk of endometrial cancer and the association with BC could not be excluded [34,35].

In order to design targeted breast cancer screening programs and to improve risk-free methods, a classification of women with BC diagnosis in accordance with risk factors could be considered [36]. Nowadays, overall survival rates for $\mathrm{BC}$ vary among different countries and generally it depends on adherence to breast cancer screening programs of the general population [1].

Although breast cancer screening can substantially reduce the burden of $B C$, some side effects, such as over-diagnosis and the related increased costs, represent possible disadvantages and could lead the general population to limited access to this fundamental preventive strategy, applied in order to reduce mortality and increase survival rates [36,37].

\section{Strategies for Prevention of Cervical Cancer}

\subsection{Primary Prevention: HPV Vaccination}

Vaccination against HPV represents the best strategy for primary prevention of cervical cancer [38]. HPV vaccines could effectively prevent pre-cancerous cervical lesions when administered before the start of sexual activity (and virus exposure) and, therefore, the World Health Organization (WHO) recommends offering HPV vaccination to all pre-adolescent girls and boys [38].

Since 2006, the HPV vaccination has been introduced through national immunization programs for girls in 71 countries, and for boys in 11 countries [22].

In 2006-2007, the Food and Drug Administration (FDA) and the European Medicines Agency (EMEA) approved two HPV vaccines containing respectively four $(6,11,16$, and 18-quadrivalent) and two antigens (16 and 18-bivalent) against HPV-serotypes [23].

Finally, in 2015, a vaccine extending antigens to five more HPV-serotypes $(31,33,45,52$, and 58 -nonavalent) in addition to the ones contained in the quadrivalent vaccine, was licensed, extending the protection against oncogenic circulating HPV-serotypes to more than 90\% [22,23] (Table 1).

The current HPV vaccination programs are mainly dedicated to preadolescents (age range 9-14 years) as primary targets, either through organized school-based vaccination plans or delivered through primary care services (including general practitioners, paediatricians, nurses, obstetrics, and gynaecologists). Moreover, according to the information provided by the Centers for Disease Control and Prevention (CDC), Advisory Committee on Immunization Practices (ACIP), HPV vaccination is also recommended for everyone by the age of $26[38,39]$. 
Table 1. Human papillomavirus (HPV) vaccines licensed and approved by international health authorities.

\begin{tabular}{cccc}
\hline Vaccine & $\begin{array}{c}\text { Number of Doses and Timing of } \\
\text { Human Papillomavirus (HPV) } \\
\text { Vaccination }\end{array}$ & $\begin{array}{c}\text { HPV-Serotypes Included in } \\
\text { the Vaccine }\end{array}$ & $\begin{array}{c}\text { Coverage of Circulating } \\
\text { Oncogenic HPV-Serotypes }\end{array}$ \\
\hline $\begin{array}{c}\text { Bivalent } \\
\text { Quadrivalent }\end{array}$ & 2: 0,6 months if $\leq 14$ years old & $\mathbf{1 6 , 1 8 *}$ & Around $75 \%$ \\
Nonavalent & 3: 0,6 months if $\geq 5$ years old & $6,11, \mathbf{1 6}, \mathbf{1 8}, \mathbf{1 8}, \mathbf{3 3}, \mathbf{4 5 , 5 2 , 5 8 *}$ & Around $75 \%$ \\
\hline
\end{tabular}

* In boldface oncogenic serotypes.

After ten years since the introduction of the vaccine and sixteen years of cervical cancer screening availability, a decrease in hospital admissions for CC and other HPV-related diseases was observed in several contexts $[20,21]$. Decreasing hospitalization rates could be attributable to several factors, including HPV vaccination, which reduces HPV infection and carcinogenesis [20]. Adherence to cervical cancer screening programs and a level of compliance over time to these preventive practices had a key role in hospitalization rates and mortality reduction as well [23].

Instead, the documented decrease in cervical cancer incidence was mainly due to HPV vaccination.

In 2014, HPV vaccination coverage reported in EU countries reached about $50 \%$ in the primary target, while in African countries a mean of $88 \%$ HPV vaccination coverage rates (VCRs) was reported [40].

A study on HPV VCRs over 31 European countries reported data largely unsatisfactory, with adherence to $\mathrm{HPV}$ vaccination ranging $\geq 71 \%$ (high) in ten countries, $51-70 \%$ in seven, $31-50 \%$ in four, and $\leq 30 \%$ (very low) in four [41].

Several factors were recognized as associated with HPV vaccine refusal, such as the education level of parents, which was discussed in several studies evidencing a discordant trend [42-44]. In England, Jean et al. showed that Local Health Units (LHUs) with higher deprivation levels had higher VCR of HPV vaccination for all doses [45]. In this and similar studies, young adults with a lower educational level had better literacy on HPV disease and vaccination and, consequently, higher rates of HPV VCRs $[46,47]$. Furthermore, a survey conducted in Sicily documented that only a very small proportion of medical students believed that genital warts can be the most frequent clinical presentation of sexually transmitted infections [48]. Of interest, a very high reduction of CC as a consequence of HPV vaccination introduction into vaccination schedule was observed in the Sicilian region $(-64 \%$ in ten years), where vaccination has been offered for free to female adolescents since 2006, as compared to data reported in Italy or in other European countries as a whole (25-40\%) [20,21,23].

Moreover, a decreasing trend in the incidence of vulvar cancers was observed among older women in Western countries, particularly in Italy, resulting in a decrease in total rate [49].

\subsection{Secondary Prevention: Cervical Cancer Screening}

The main tests available for cervical cancer screening are Papanicolau (Pap) test, offered every three years to women between the ages of 25 and 30 (and until 64 years old in other countries that had not introduced other screening tests), and the human papillomavirus DNA testing (HPV-DNA test) offered every five years to women between 30 and 64 years old [50,51] (Table 2).

Table 2. Cervical cancer screening tests authorized by international health authorities.

\begin{tabular}{cccc}
\hline $\begin{array}{c}\text { Cervical Cancer } \\
\text { Screening Test }\end{array}$ & Timing & Age Range & $\begin{array}{c}\text { Confirmation Test for } \\
\text { Positive }\end{array}$ \\
\hline Papanicolau (Pap) test & Every three years & $\begin{array}{c}\text { 25-64 years or 25-31 years } \\
\text { (if associated with HPV-DNA test) }\end{array}$ & Colposcopy \\
\hline HPV-DNA test & Every five years & 31-64 years & Pap test and colposcopy \\
\hline
\end{tabular}

Even though the test used so far has been the Pap test, recent scientific evidence has found that over 30 years of age the most cost-effective is the HPV-DNA test $[52,53]$. 
The mortality reduction for CC that can be achieved by a universal screening program depends on several factors [54].

These include the epidemiology of HPV infection in the population and the characteristics of the screening program, including type of offer, starting and stopping ages, performance of screening activities (calculated as sensitivity and specificity) screening interval, adherence and quality of follow-up [55].

These parameters can vary among different countries and regions and the observed reductions in CC mortality could also vary $[56,57]$.

Several studies reported a reduction in CC mortality in women attending screening compared with non-attendees, although not all studies reported whether there was a significant reduction [58]. In cohort studies conducted among women that attended organized screening programs, the CC mortality reduction ranged between $17 \%$ and $79 \%$ in Northern Europe [59].

Moreover, a reduction ranging between $51 \%$ and $86 \%$ of CC mortality was observed in women participating in an organized screening program, corrected for self-selection bias [60].

Additionally, a systematic review showed that data on efficacy of the HPV screening in CC mortality reduction were consistent in randomized intervention trials and observational studies conducted in many countries [61].

Many countries are planning to modify their screening program, and among them Italy has stated the intention to implement the new screening test based on the search for high risk HPV infection at the end of 2020 [51]. If the HPV test is positive, the woman must undergo a Pap test which could appropriately select women who have cellular changes and should proceed with the colposcopy.

If the cytology does not show important alterations, the HPV test will be repeated after one year [51].

Instead, from age 25 to 30 the reference remains the Pap test to be performed every three years. HPV-DNA tests demonstrated higher sensitivity and specificity than cytology in identifying cervical intraepithelial neoplasia or cancer in women aged $\geq 31$ years old $[62,63]$.

These results should be used as a benchmark for using similar screening tests in other countries [64]. In Europe, $63.6 \%$ of the target populations of any age and $59.2 \%$ of aged $30-59$ years were invited for cervical screening [65].

Only $26.1 \%$ of the target population (any age) had cervical screening after invitation ( $29.8 \%$ restricted to the age range 30-59 years) [65]. However, the previous coverages did not include opportunistic activity [66].

Exploring reasons associated with CC screening adherence is essential. Several factors could reduce cervical cancer screening rates including low educational level, poor self-reported health status, country of origin, and having a comorbidity $[67,68]$.

Lastly, it was discovered that counselling from obstetrician-gynaecologists has higher CC screening adherence rates among patients than counselling from a general practitioner (GP) or other physician which were, in any case, positively associated with Pap testing adherence [69].

\section{Strategies for Prevention of Breast Cancer}

\subsection{Primary Prevention: Removing Risk Factors}

Several risk factors for $\mathrm{BC}$ have been documented and some of these could be prevented through correct lifestyles [70,71].

Immutable factors include how a familial history (first-degree relative or multiple family members) of $\mathrm{BC}$ increases the risk similar to a personal history of breast cancer or certain non-cancerous breast diseases such as atypical hyperplasia [72,73].

Moreover, older age and some genetic mutations, particularly in BRCA1, BRCA2, and p53 genes are strongly related with breast cancers, especially at younger ages [73,74]. 
Differences in BC incidence between developed and developing countries were probably associated with different modifiable factors [71] (Table 3).

Table 3. Risk and protective modifiable factors associated with breast cancer incidence.

\begin{tabular}{ccc}
\hline Modifiable Factors for Breast Cancer & Increased Risk & Decreased Risk \\
\hline Childbirth & Later & Prior \\
\hline Parity & Nulliparity or Lower & Higher \\
\hline Breastfeeding & Short or null & Long \\
\hline Menarche & $<12$ years & $\geq 12$ years \\
\hline Menopause & $\leq 55$ years & $>55$ years \\
\hline Oestrogen exposure & Prolonged oral contraceptive or & No hormonal therapies \\
\hline hietary habits & Diet rich of animal fat and proteins & $\begin{array}{c}\text { Diet rich of fruit and vegetables } \\
\text { (Mediterranean Diet) }\end{array}$ \\
\hline Physical activity & Inactive & Active \\
\hline Alcohol & High intake & Low or no intake \\
\hline Weight & Overweight or obesity & Normal weight
\end{tabular}

With regard to modifiable risk factors, a prolonged exposure to endogenous oestrogens, early menarche ( $<12$ years), late menopause ( $>55$ years) or oral contraceptive and hormone replacement therapy, are all associated with an increased risk of BC $[75,76]$.

Furthermore, some factors related to pregnancy such as late age at first childbirth or nulliparity increase the risk of a BC diagnosis, while breastfeeding is a protective factor [77]. Also, later first childbirth is associated with higher incidence rate of breast cancer [71].

High alcohol intake, overweight and obesity, unhealthy diet and physical inactivity are known risk factors as well [78-80]. A diet based mainly on a prevalent intake of vegetable fat and proteins and a limited intake of animal fat and proteins (such as reported by the principles of the Mediterranean Diet), was strongly associated with lower levels of endogenous estrogens in healthy postmenopausal women.

The dietary components of this diet more effectively decrease estrogen levels and could represent preventive measures for BC [81,82].

Moreover, previous treatment using radiation therapy to the chest or breasts (like for treatment of Hodgkin's lymphoma) has been also associated with BC insurgence [83].

\subsection{Secondary Prevention: Breast Cancer Screening}

Mammography is the elective screening modality recognized to reduce BC mortality [84]. Furthermore, particularly in a dense breast (typical of younger women), supplemental screening for BC with other imaging modalities such as ultrasonography should be considered $[85,86]$.

An ecological study confirmed a positive association between the implementation of organized mammography screening programs (MSPs) and the reduction over the last decades of BC mortality rates throughout western European countries ranging from $-1.5 \%$ to $-5.4 \%(50-59),-0.2 \%$ to $-8.1 \%$ (60-69) and 0\% to $-7.1 \%(70-79)$ [87].

Approximately 95\% of the 67.5 million women aged 50 to 69 , who the European Council recommended as an eligible age for BC screening, were screened in the European Union in 2016 [65]. These women were residents of member states that have adopted policies to plan and implement BC population-based screening programmes [65].

Specifically, among 13.1 million mammography tests performed, the overall detection rate for carcinoma in situ (CIS) and invasive breast cancers (defined as "malignancy detection rate") was of 6.2 per 1000 women screened in the age range 50-69 years, while for the age groups 45-49 years and 70-74 years the rate was of 4.3 and 9.5 per 1000, respectively [65]. 
An effective breast cancer screening program also increases the incidence of cancer detected at an early stage and decreases the incidence of cancer presenting at a later stage [88,89].

European guidelines suggest no screening for women aged 40 to 44 years, whereas the incidence of $B C$ and mortality increases with age and the absolute health benefits are greater in women aged 45 to 49 than those aged 40 to 44 years [89].

Studies report that BC mortality rates are higher amongst women of more deprived areas who are less likely to attend breast cancer screening programmes [90].

For asymptomatic women aged 45 to 49 years without a high risk for $\mathrm{BC}$, guidelines suggest a mammography screening every 2 or 3 years, while for women aged 50-69 a screening every 2 years, and lastly for women aged 70-74 every 3 years [89].

This data was confirmed in the 2017 Report of the European Commission about cancer screening, highlighting that the age range 50-69 years is the widest target for breast cancer screening recommended by the European Council (approximately 32 million women per year) and it is common to most of the national programmes of European countries [90].

The participation rate to screening programs in the entire EU in 2013 for the age group 50-69 years was $60.2 \%$ on almost 24 million total invitations, while for $45-49$ years it was $68.9 \%$ and for $70-74$ years $60.4 \%$ (on less than 1 million invitations each) [65].

Despite these results, there are still some barriers to a complete adhesion to breast screening programs such as lack of awareness and of correct information, misperceptions and wrong attitudes toward health, femininity and cancer prevention (often futile reasons such as forgetfulness, laziness, or lack of time) [91-93].

General practitioners could also play a role in such communication by providing scientifically sound information on breast cancer screening [94].

Novel technologies could help in the early diagnosis of $B C$ and could integrate or substitute the actual procedures used in breast cancer screening $[95,96]$.

Lastly, advanced technological methods such as next-generation targeted panel sequencing demonstrated a fundamental role for the evolution of future BC screening programs [97]. These most recent promising and accurate modern techniques of precision oncology are actually not available on a large scale and their role should be considered in cancer screening and diagnosis-related fields [98].

\section{Conclusions}

The review of the scientific literature allowed us to document an up-to-date epidemiological picture and at the same time to highlight the effectiveness of vaccination and screening in limiting the burden of the disease of cervical and breast cancers, two of the main preventable female tumours.

Among females, $\mathrm{BC}$ is the most commonly diagnosed cancer and the leading cause of cancer death, while CC ranks fourth for both incidence and mortality [99].

In particular, within gynaecologic cancers, the ones originating in the female reproductive organs, $\mathrm{CC}$ is in the top five of the main types of female tumours [99].

A number of common cancers among females, and above all cervical and breast neoplasia, have known means of prevention and/or early detection which can be applied in resource-appropriate settings [17]. To counteract the burden of the female cancers recalled, anti-HPV vaccination and preventive measures against risk factors represent the main primary prevention strategies, while mammography and cervical cancer screening are the most effective approaches.

On one side, the global burden of cancer among women is considerable but on the other, there is a significant potential to reduce morbidity and mortality due to female cancers, as well as to alleviate the economic impact of these diseases on individuals, families, and healthcare systems [1].

Moreover, dedicated prevention protocols should be considered to protect vulnerable populations like female migrants/refugees, considered at higher risk for CC incidence, whereas evidence suggests that women with a migration background of $\mathrm{BC}$ tend to acquire the same exposure risk of and are less likely to participate in mammography screenings than autochthonous women [100-102]. In the 
future, preventive measures should be adopted to limit the burden of incidence and mortality of female cancers and be actively offered to the general population in developed and less developed countries.

The contrast of health inequalities should be considered a priority for international public health institutions by improving access to preventive interventions (such as HPV vaccination) or early diagnosis (such as cervical and breast cancer screening).

Funding: This research received no external funding.

Conflicts of Interest: The authors declare no conflict of interest.

\section{References}

1. Torre, L.A.; Islami, F.; Siegel, R.L.; Ward, E.M.; Jemal, A. Global Cancer in Women: Burden and Trends. Cancer Epidemiol. Biomark. Prev. 2017, 26, 444-457. [CrossRef] [PubMed]

2. United Nations Population Division. World Population Prospects, the 2015 Revision. 2015. Available online: https://esa.un.org/unpd/wpp/ (accessed on 31 July 2020).

3. Franceschi, S.; Wild, C.P. Meeting the global demands of epidemiologic transition the indispensable role of cancer prevention. Mol. Oncol. 2013, 7, 1-13. [CrossRef] [PubMed]

4. World Health Organization. Women and Health: Today's Evidence, Tomorrow's Agenda. 2009. Available online: https://apps.who.int/iris/bitstream/handle/10665/44168/9789241563857_eng.pdf;jsessionid= D3CA9370C64B015B65B7C931B88663D6? sequence $=1$ (accessed on 31 July 2020).

5. Bray, F.; Ren, J.S.; Masuyer, E.; Ferlay, J. Global estimates of cancer prevalence for 27 sites in the adult population in 2008. Int. J. Cancer 2013, 132, 1133-1145. [CrossRef] [PubMed]

6. Farmer, P.; Frenk, J.; Knaul, F.M. Expansion of cancer care and control in countries of low and middle income: A call to action. Lancet 2010, 376, 1186-1193. [CrossRef]

7. Francisci, S.; Guzzinati, S.; Capodaglio, G.; Pierannunzio, D.; Mallone, S.; Tavilla, A.; Lopez, T.; Busco, S.; Mazzucco, W.; Angiolini, C.; et al. Patterns of care and cost profiles of women with breast cancer in Italy: EPICOST study based on real world data. Eur. J. Health Econ. 2020. [CrossRef]

8. Allemani, C.; Matsuda, T.; Di Carlo, V.; Harewood, R.; Matz, M.; Nikšić, M.; Bonaventure, A.; Valkov, M.; Johnson, C.J.; Estève, J.; et al. Global surveillance of trends in cancer survival 2000-14 (CONCORD-3): Analysis of individual records for $37,513,025$ patients diagnosed with one of 18 cancers from 322 population-based registries in 71 countries. Lancet 2018, 391, 1023-1075. [CrossRef]

9. Bielska-Lasota, M.; Rossi, S.; Krzyżak, M.; Annemie Haelens, A.; Domenic, A.; De Angelis, R.; Maciejczyk, A.; Rodríguez-Barranco, M.; Zadnik, V.; Minicozzi, P.; et al. Reasons for low cervical cancer survival in new accession European Union countries: A EUROCARE-5 study. Arch. Gynecol. Obstet. 2020, 301, 591-602. [CrossRef]

10. Danaei, G.; Vander Hoorn, S.; Lopez, A.D.; Murray, C.J.L.; Ezzati, M.; Comparative Risk Assessment Collaborating Group (Cancers). Causes of cancer in the world: Comparative risk assessment of nine behavioural and environmental risk factors. Lancet 2005, 366, 1784-1793. [CrossRef]

11. Ezzati, M.; Vander Hoorn, S.; Lopez, A.D.; Danaei, G.; Rodgers, A.; Mathers, C.D.; Murray, C.J.L.; Lopez, A.D.; Mathers, C.D.; Ezzati, M.; et al. Comparative quantification of mortality and burden of disease attributable to selected risk factors. In Global Burden of Disease and Risk Factors; The World Bank and Oxford University Press: Washington, DC, USA, 2006; pp. 241-396.

12. Zorzi, M.; Mangone, L.; Anghinoni, E.; Baracco, S.; Borciani, E.; Caldarella, A.; Falcini, F.; Fanetti, A.C.; Ferretti, S.; Rossi, P.G.; et al. Characteristics of the colorectal cancers diagnosed in the early 2000s in Italy. Figures from the IMPATTO study on colorectal cancer screening. Epidemiol. Prev. 2015, 39, 108-114.

13. Zorzi, M.; Mangone, L.; Sassatelli, R.; Baracco, S.; Budroni, M.; Castaing, M.; Cirilli, C.; Cusimano, R.; Fusco, M.; Giacomin, A.; et al. Incidence trends of colorectal cancer in the early 2000s in Italy. Figures from the IMPATTO study on colorectal cancer screening. Epidemiol. Prev. 2015, 39 (Suppl. 1), 1-125.

14. Cohen, P.A.; Jhingran, A.; Oaknin, A.; Denny, L. Cervical cancer. Lancet 2019, 393, 169-182. [CrossRef]

15. Siegel, R.; Ma, J.; Zou, Z.; Jemal, A. Cancer statistics. CA Cancer J. Clin. 2014, 64, 9-29. [CrossRef] [PubMed]

16. International Agency for Research on Cancer: Lyon-IARC. Monographs on the Evaluation of Carcinogenic Risks to Humans Volume 90: Human Papillomaviruses. 2007. Available online: https://publications.iarc.fr/108 (accessed on 31 July 2020). 
17. Matz, M.; Coleman, M.P.; Sant, M.; Chirlaque, M.D.; Visser, O.; Gore, M.; Allemani, C.; CONCORD Working Group. The histology of ovarian cancer: Worldwide distribution and implications for international survival comparisons (CONCORD-2). Gynecol. Oncol. 2017, 144, 405-413. [CrossRef] [PubMed]

18. Centers for Disease Control and Prevention-CDC. Inside Knowledge: Get the Facts about Gynecologic Cancer. 2005. Available online: https://www.cdc.gov/cancer/gynecologic/knowledge/index.htm (accessed on 31 July 2020).

19. Natioal Cancer Institute. Bethesda. Cancer Stat Facts: Cervical Cancer. 2020. Available online: https: //seer.cancer.gov/statfacts/html/cervix.html (accessed on 31 July 2020).

20. Peirson, L.; Fitzpatrick-Lewis, D.; Ciliska, D.; Warren, R. Screening for cervical cancer: A systematic review and meta-analysis. Syst. Rev. 2013, 2, 35. [CrossRef]

21. Restivo, V.; Costantino, C.; Amato, L. Evaluation of the Burden of HPV-Related Hospitalizations as a Useful Tool to Increase Awareness: 2007-2017 Data from the Sicilian Hospital Discharge Records. Vaccines (Basel) 2020, 8, 47. [CrossRef]

22. Drolet, M.; Bernard, E.; Perez, N.; Brisson, M.; HPV Vaccination Impact Study Group. Population-level impact and herd effects following the introduction of human papillomavirus vaccination programmes: Updated systematic review and meta-analysis. Lancet 2019, 394, 497-509. [CrossRef]

23. Trucchi, C.; Costantino, C.; Restivo, V. Immunization Campaigns and Strategies against Human Papillomavirus in Italy: The Results of a Survey to Regional and Local Health Units Representatives. BioMed Res. Int. 2019, 2019, 6764154. [CrossRef]

24. Markowitz, L.E.; Hariri, S.; Lin, C.; Dunne, E.F.; Steinau, M.; McQuillan, G.; Unger, E.R. Reduction in human papillomavirus (HPV) prevalence among young women following HPV vaccine introduction in the United States, National Health and Nutrition Examination Surveys, 2003-2010. J. Infect. Dis. 2013, 208, 385-393. [CrossRef]

25. Tsikouras, P.; Zervoudis, S.; Manav, B.; Tomara, E.; Iatrakis, G.; Romanidis, R.; Bothou, A.; Galazios, G. Cervical cancer: Screening, diagnosis and staging. J. Buon 2016, 21, 320-325.

26. Gerstl, B.; Sullivan, E.; Vallejo, M.; Koch, J.; Johnson, M.; Wand, H.; Webber, K.; Ives, A.; Anazodo, A. Reproductive outcomes following treatment for a gynecological cancer diagnosis: A systematic review. J. Cancer Surv. 2019, 13, 269-281. [CrossRef]

27. Hillemanns, P.; Soergel, P.; Hertel, H.; Jentschke, M. Epidemiology and Early Detection of Cervical Cancer. Oncol. Res. Treat. 2016, 39, 501-506. [CrossRef] [PubMed]

28. Cortessis, V.K.; Barrett, M.; Brown Wade, N.; Enebish, T.; Perrigo, J.L.; Tobin, J.; Zhong, C.; Zink, J.; Isiaka, V.; Muderspach, L.I.; et al. Intrauterine Device Use and Cervical Cancer Risk: A Systematic Review and Meta-analysis. Obstet. Gynecol. 2017, 130, 1226-1236. [CrossRef] [PubMed]

29. World Cancer Research Fund-American Institute for Cancer Research. Breast Cancer Statistics. Available online: https://www.wcrf.org/dietandcancer/cancer-trends/breast-cancer-statistics (accessed on 31 July 2020).

30. Winters, S.; Martin, C.; Murphy, D.; Shokar, N.K. Breast Cancer Epidemiology, Prevention, and Screening. Prog. Mol. Biol. Transl. Sci. 2017, 151, 1-32. [PubMed]

31. Tao, Z.; Shi, A.; Lu, C.; Song, T.; Zhang, Z.; Zhao, J. Breast Cancer: Epidemiology and Etiology. Cell. Biochem. Biophys. 2015, 72, 333-338. [CrossRef]

32. Youlden, D.R.; Cramb, S.M.; Dunn, N.A.; Muller, J.M.; Pyke, C.M.; Baade, P.D. The descriptive epidemiology of female breast cancer: An international comparison of screening, incidence, survival and mortality. Cancer Epidemiol. 2012, 36, 237-248. [CrossRef]

33. Franceschini, G.; Di Leone, A.; D’Archi, S.; Masetti, R. Oral contraceptives and breast cancer risk: An overestimated risk? Crit. Rev. Oncol. Hematol. 2020, 147, 102876. [CrossRef]

34. Hunter, D.J. Oral Contraceptives and the Small Increased Risk of Breast Cancer. N. Engl. J. Med. 2017, 377, 2276-2277. [CrossRef]

35. Coughlin, S.S. Epidemiology of Breast Cancer in Women. Adv. Exp. Med. Biol. 2019, 1152, 9-29.

36. Niell, B.L.; Freer, P.E.; Weinfurtner, R.J.; Arleo, E.K.; Drukteinis, J.S. Screening for Breast Cancer. Radiol. Clin. N. Am. 2017, 55, 1145-1162. [CrossRef]

37. Kolak, A.; Kamińska, M.; Sygit, K.; Budny, A.; Surdyka, D.; Kukiełka-Budny, B.; Burdan, F. Primary and secondary prevention of breast cancer. Ann. Agric. Environ. Med. 2017, 24, 549-553. [CrossRef] 
38. Center for Disease Control and Prevention. HPV Vaccine Reccomendations. Available online: https://www.cdc. gov/vaccines/vpd/hpv/hcp/recommendations.html\#: \{\}:text=HPV\%20vaccine\%20is\%20recommended\%20for, if $\% 20$ not $\% 20$ adequately $\% 20$ vaccinated $\% 20$ previously.\%20Please $\% 20$ provide $\% 20$ this $\% 20$ information $\% 20$ in $\%$ 20\%E2\%80\%9CPreliminary\%20prevention:\%20HPV\%20vaccination\%E2\%80\%9D (accessed on 4 October 2020).

39. Costantino, C.; Amodio, E.; Vitale, F.; Trucchi, C.; Maida, C.M.; Bono, S.E.; Caracci, F.; Sannasardo, C.E.; Scarpitta, F.; Vella, C.; et al. Human Papilloma Virus Infection and Vaccination: Pre-Post Intervention Analysis on Knowledge, Attitudes and Willingness to Vaccinate Among Preadolescents Attending Secondary Schools of Palermo, Sicily. Int. J. Environ. Res. Public Health 2020, 17, 5362. [CrossRef] [PubMed]

40. Bruni, L.; Diaz, M.; Barrionuevo-Rosas, L.; Herrero, R.; Bray, F.; Bosch, F.V.; de Sanjosé, D.; Castellsagué, X. Global estimates of human papillomavirus vaccination coverage by region and income level: A pooled analysis. Lancet Glob. Health 2016, 4, e453-e463. [CrossRef]

41. Nguyen-Huu, N.; Thilly, N.; Derrough, T.; Sdona, E.; Claudot, F.; Pulcini, C.; Agrinier, N. HPV Policy working group. Human papillomavirus vaccination coverage, policies, and practical implementation across Europe. Vaccine 2020, 38, 1315-1331. [CrossRef]

42. Restivo, V.; Costantino, C.; Fazio, T.F.; Casuccio, N.; D’Angelo, C.; Vitale, F.; Casuccio, A. Factors Associated with HPV Vaccine Refusal among Young Adult Women after Ten Years of Vaccine Implementation. Int. J. Environ. Res. Public Health 2018, 15, 770. [CrossRef]

43. Palmeri, S.; Costantino, C.; D'Angelo, C.; Casuccio, N.; Ventura, G.; Vitale, F.; Pojero, F.; Casuccio, A. HPV vaccine hesitancy among parents of female adolescents: A pre-post interventional study. Public Health 2017, 150, 84-86. [CrossRef] [PubMed]

44. Icardi, G.; Costantino, C.; Guido, M.; Zizza, A.; Restivo, V.; Amicizia, D.; Tassinari, F.; Piazza, M.F.; Paganino, C.; Casuccio, A.; et al. Burden and Prevention of HPV. Knowledge, Practices and Attitude Assessment among Pre-Adolescents and their Parents in Italy. Curr. Pharm. Des. 2020, 26, 326-342. [CrossRef]

45. Jean, S.; Elshafei, M.; Buttenheim, A. Social determinants of community-level human papillomavirus vaccination coverage in a school-based vaccination programme. Sex. Transm. Infect. 2018, 94, 248-253. [CrossRef]

46. Lee, H.Y.; Lee, J.; Henning-Smith, C.; Choi, J. HPV literacy and its link to initiation and completion of HPV vaccine among young adults in Minnesota. Public Health 2017, 152, 172-178. [CrossRef]

47. Trucchi, C.; Amicizia, D.; Tafuri, S.; Sticchi, L.; Durando, P.; Costantino, C.; Varlese, F.; Di Silverio, B.; Bagnasco, A.M.; Ansaldi, F.; et al. Assessment of Knowledge, Attitudes, and Propensity towards HPV Vaccine of Young Adult Students in Italy. Vaccines 2020, 8, 74. [CrossRef]

48. Cerame, G.; Meli, V.; Vitale, F.; Firenze, A.; Viviano, E.; Mazzucco, W.; Romano, N. A study to evaluate the lifestyle of medical students in Palermo (Italy). Igiene e Sanità Pubblica 2008, 64, 473-488.

49. Mancini, S.; Bucchi, L.; Baldacchini, F.; Giuliani, O.; Ravaioli, A.; Vattiato, R.; Preti, M.; Tumino, R.; Ferretti, S.; Biggeri, A.; et al. Incidence trends of vulvar squamous cell carcinoma in Italy from 1990 to 2015. Gynecol. Oncol. 2020, 157, 656-663. [CrossRef] [PubMed]

50. Lytwyn, A.; Elit, L.; Sellors, J.W. Human papillomavirus DNA versus papanicolaou screening tests for cervical cancer. N. Engl. J. Med. 2008, 358, 641.

51. Cervical Cancer Screening. Italian Ministry of Health. Available online: http://www.salute.gov.it/portale/ donna/dettaglioContenutiDonna.jsp?lingua=italiano\&id=4511\&area=Salute $\% 20$ donna\&menu=prevenzione (accessed on 31 July 2020).

52. Zorzi, M.; Del Mistro, A.; Farruggio, A.; de’Bartolomeis, L.; Frayle-Salamanca, H.; Baboci, L.; Bertazzo, A.; Cocco, P.; Fedato, C.; Gennaro, M.; et al. Use of a high-risk human papillomavirus DNA test as the primary test in a cervical cancer screening programme: A population-based cohort study. BJOG 2013, 120, 1260-1267. [CrossRef] [PubMed]

53. Goodman, A. HPV testing as a screen for cervical cancer. BMJ 2015, 350, h2372. [CrossRef] [PubMed]

54. Miranda, N.C.; Podolsky, M.L. Cervical Cancer Screening. Obstet. Gynecol. 2016, 128, 205. [CrossRef]

55. Landy, R.; Pesola, F.; Castañón, A.; Sasieni, P. Impact of cervical screening on cervical cancer mortality: Estimation using stage-specific results from a nested case-control study. Br. J. Cancer 2016, 115, 1140-1146. [CrossRef] [PubMed]

56. Vaccarella, S.; Franceschi, S.; Zaridze, D.; Poljak, M.; Veerus, P.; Plummer, M.; Bray, F. Preventable fractions of cervical cancer via effective screening in six Baltic, central, and eastern European countries 2017-40: A population-based study. Lancet Oncol. 2016, 17, 1445-1452. [CrossRef] 
57. Van Ballegooijen, M.; Van Den Akker-van Marle, E.; Patnick, J.; Lynge, E.; Arbyn, M.; Anttila, A.; Ronco, G.; Dik, J.; Habbema, F. Overview of important cervical cancer screening process values in European Union (EU) countries, and tentative predictions of the corresponding effectiveness and cost-effectiveness. Eur. J. Cancer 2000, 36, 2177-2188. [CrossRef]

58. Wentzensen, N.; Arbyn, M. HPV-based cervical cancer screening-facts, fiction, and misperceptions. Prev. Med. 2017, 98, 33-35. [CrossRef]

59. Jansen, E.E.L.; Zielonke, N.; Gini, A.; Anttila, A.; Segnan, N.; Vokó, Z.; Ivanuš, U.; McKee, M.; de Koning, H.J.; de Kok, I.M.C.M.; et al. Effect of organized cervical cancer screening on cervical cancer mortality in Europe: A systematic review. Eur. J. Cancer 2020, 127, 207-223. [CrossRef]

60. Lönnberg, S.; Nieminen, P.; Luostarinen, T.; Anttila, A. Mortality audit of the Finnish cervical cancer screening program. Int. J. Cancer 2013, 132, 2134-2140. [CrossRef] [PubMed]

61. Rozemeijer, K.; de Kok, I.M.; Naber, S.K.; van Kemenade, F.J.; Penning, C.; van Rosmalen, J.; van Ballegooijen, M. Offering self-sampling to non-attendees of organized primary HPV screening: When do harms outweigh the benefits? Cancer Epidemiol. Biomark. Prev. 2015, 24, 773-782. [CrossRef]

62. Vicus, D.; Sutradhar, R.; Lu, Y.; Elit, L.; Kupets, R.; Paszat, L.; Investigators of the Ontario Cancer Screening Research Network. The association between cervical cancer screening and mortality from cervical cancer: A population based case-control study. Gynecol Oncol. 2014, 133, 167-171. [CrossRef]

63. Rijkaart, D.C.; Berkhof, J.; Rozendaal, L.; van Kemenade, F.J.; Bulkmans, N.W.J.; Heideman, D.A.M.; Kenter, G.G.; Cuzick, J.; Snijders, P.J.F.; Meijer, C.J.L.M. Human papillomavirus testing for the detection of high-grade cervical intraepithelial neoplasia and cancer: Final results of the POBASCAM randomised controlled trial. Lancet Oncol. 2012, 13, 78-88. [CrossRef]

64. Kitchener, H.C.; Gilham, C.; Sargent, A.; Bailey, A.; Albrow, R.; Roberts, C.; Desai, M.; Mather, J.; Turner, A.; Moss, S.; et al. A comparison of HPV DNA testing and liquid based cytology over three rounds of primary cervical screening: Extended follow up in the ARTISTIC trial. Eur. J. Cancer 2011, 47, 864-871. [CrossRef] [PubMed]

65. Adab, P.; McGhee, S.M.; Yanova, J.; Wong, C.M.; Hedley, A.J. Effectiveness and efficiency of opportunistic cervical cancer screening: Comparison with organized screening. Med. Care 2004, 42, 600-609. [CrossRef]

66. Ponti, A.; Anttila, A.; Ronco, G.; Senore, C. Cancer Screening in the European Union: Report on the Implementation of the Council Recommendation on Cancer Screening. European Commission. 2017. Available online: https://ec.europa.eu/health/sites/health/files/major_chronic_diseases/docs/2017_ cancerscreening_2ndreportimplementation_en.pdf (accessed on 31 July 2020).

67. Osservatorio Nazionale Screening. Data on Cervical Cancer Screening Adherence in Italy. Available online: https://www.osservatorionazionalescreening.it/sites/default/files/allegati/screening_cervice_light.pdf (accessed on 31 July 2020).

68. Worthington, C.; McLeish, K.; Fuller-Thomson, E. Adherence over time to cervical cancer screening guidelines: Insights from the Canadian National Population Health Survey. J. Women's Health 2012, 21, 199-208. [CrossRef]

69. Costantino, C.; Mazzucco, W.; Marotta, C.; Saporito, L.; Bono, S.E.; Fiorino, G.R.; Graziano, G.; Maniglia, M.; Marchese, V.; Napoli, G.; et al. Methodological issues in a cross-sectional survey on cervical cancer screening using telephone interviews in Sicily (Italy): A SWOT analysis. J. Int. Med. Res. 2019, 47, 5174-5184. [CrossRef]

70. Coughlin, S.S.; Breslau, E.S.; Thompson, T.; Benard, V.B. Physician recommendation for papanicolaou testing among U.S. women. Cancer Epidemiol. Biomark. Prev. 2005, 14, 1143-1148. [CrossRef]

71. World Health Organization. Breast Cancer: Prevention and Control. Available online: https://www.who.int/ cancer/detection/breastcancer/en/index2.html (accessed on 31 July 2020).

72. Centers for Disease Control and Prevention. What Are the Risk Factors for Breast Cancer? Available online: https://www.cdc.gov/cancer/breast/basic_info/risk_factors.htm (accessed on 31 July 2020).

73. James, V.; Lacey, J.V., Jr.; Aimee, R.K.; Saundra, S.B.; Marcus, P.M.; Chang, S.C.; Leitzmann, M.F.; Hoover, R.N.; Prorok, P.C.; Berg, C.D.; et al. Breast cancer epidemiology according to recognized breast cancer risk factors in the Prostate, Lung, Colorectal and Ovarian (PLCO) Cancer Screening Trial Cohort. BMC Cancer 2009, 17,84 .

74. Wendt, C.; Margolin, S. Identifying breast cancer susceptibility genes-a review of the genetic background in familial breast cancer. Acta Oncol. 2019, 58, 135-146. [CrossRef] 
75. Mahdavi, M.; Nassiri, M.; Mahdi Kooshyar, M.; Vakili-Azghandi, M.; Avan, A.; Sandry, R.; Pillai, S.; Lam, A.K.; Gopalan, V. Hereditary Breast Cancer; Genetic Penetrance and Current Status with BRCA. J. Cell. Physiol. 2019, 234, 5741-5750. [CrossRef]

76. Zolfaroli, I.; Tarín, J.J.; Cano, A. The action of estrogens and progestogens in the young female breast. Eur. J. Obstet. Gynecol. Reprod. Biol. 2018, 230, 204-207. [CrossRef] [PubMed]

77. Russo, J.; Moral, R.; Balogh, G.A.; Mailo, D.; Russo, I.H. The protective role of pregnancy in breast cancer. Breast Cancer Res. 2005, 7, 131-142. [CrossRef] [PubMed]

78. Friedenreich, C.M.; Neilson, H.K.; Lynch, B.M. State of the epidemiological evidence on physical activity and cancer prevention. Eur. J. Cancer 2010, 46, 2593-2604. [CrossRef]

79. Chen, W.Y.; Rosner, B.; Hankinson, S.E.; Colditz, G.A.; Willett, W.C. Moderate alcohol consumption during adult life, drinking patterns, and breast cancer risk. JAMA 2011, 306, 1884-1890. [CrossRef] [PubMed]

80. Farvid, M.S.; Chen, W.Y.; Michels, K.B.; Cho, E.; Willett, W.C.; Eliassen, A.H. Fruit and vegetable consumption in adolescence and early adulthood and risk of breast cancer: Population based cohort study. BMJ 2016, 353, i12343. [CrossRef]

81. Turati, F.; Carioli, G.; Bravi, F.; Ferraroni, M.; Serraino, D.; Montella, M.; Giacosa, A.; Toffolutti, F.; Negri, E.; Levi, F.; et al. Mediterranean Diet and Breast Cancer Risk. Nutrients 2018, 10, 326. [CrossRef]

82. Carruba, G.; Granata, O.M.; Pala, V.; Campisi, I.; Agostara, B.; Cusimano, R.; Ravazzolo, B.; Traina, A. A traditional Mediterranean diet decreases endogenous estrogens in healthy postmenopausal women. Nutr. Cancer 2006, 56, 253-259. [CrossRef]

83. Hancock, S.L.; Tucker, M.A.; Hoppe, R.T. Breast cancer after treatment of Hodgkin's disease. J. Natl. Cancer Inst. 1993, 85, 25-31. [CrossRef]

84. Arnold, M.; Karim-Kos, H.E.; Coebergh, J.W.; Byrnes, G.; Antilla, A.; Ferlay, J.; Renehan, A.G.; Forman, D.; Soerjomataram, I. Recent trends in incidence of five common cancers in 26 European countries since 1988: Analysis of the European Cancer observatory. Eur. J. Cancer 2015, 51, 1164-1187. [CrossRef]

85. Iwamoto, Y.; Kaucher, S.; Lorenz, E.; Bärnighausen, T.; Winkler, V. Development of breast cancer mortality considering the implementation of mammography screening programs-A comparison of western European countries. BMC Public Health 2019, 19, 823. [CrossRef] [PubMed]

86. Filipe, M.D.; Patuleia, S.I.S.; de Jong, V.M.T.; Vriens, M.R.; van Diest, P.J.; Witkamp, A.J. Network Meta-analysis for the Diagnostic Approach to Pathologic Nipple Discharge. Clin. Breast Cancer 2020, 8. [CrossRef]

87. Health Quality Ontario. Ultrasound as an adjunct to mammography for breast cancer screening: A health technology assessment. Ont. Health Technol. Assess. Ser. 2016, 16, 1-71.

88. Moss, S.; Waller, M.; Anderson, T.J.; Cuckle, H. Trial Management Group. Randomised controlled trial of mammographic screening in women from age 40: Predicted mortality based on surrogate outcome measures. Br. J. Cancer 2005, 92, 955-960. [CrossRef] [PubMed]

89. Thompson, A.M.; Moulder-Thompson, S.L. Neoadjuvant therapy of breast cancer. Ann. Oncol. 2012, 23, 231-236. [CrossRef]

90. International Agency for Research on Cancer. Cancer Screening in the European Union: Report on the Implementation of the Council Recommendation on Cancer Screening. Available online: https:/ec.europa.eu/ health/sites/health/files/major_chronic_diseases/docs/2017_cancerscreening_2ndreportimplementation_en.pdf (accessed on 4 October 2020).

91. Schünemann, H.J.; Lerda, D.; Quinn, C.; Follmann, M.; Alonso-Coello, P.; Giorgi Rossi, P.; Lebeau, A.; Nyström, L.; Broeders, M.; Ioannidou-Mouzaka, L.; et al. Breast cancer screening and diagnosis: A synopsis of the European Breast Guidelines. Ann. Intern. Med. 2020, 172, 46-56. [CrossRef]

92. Wu, T.Y.; Lee, J. Promoting Breast Cancer Awareness and Screening Practices for Early Detection in Low-Resource Settings. Eur. J. Breast Health 2018, 15, 18-25. [CrossRef]

93. Kwok, C.; Tranberg, R.; Lee, F.C. Breast cancer knowledge, attitudes and screening behaviors among Indian-Australian women. Eur. J. Oncol. Nurs. 2015, 19, 701-706. [CrossRef]

94. Valent, F.; Sammartano, F.; Degano, S.; Dellach, C.; Franzo, A.; Gerin, D.; Gnesutta, D.; Mentil, S.; Stel, S.; Pattitoni, C.; et al. Reasons for non-participation in public oncological screening programs in the Italian region Friuli Venezia Giulia. Public Health 2020, 181, 80-85. [CrossRef]

95. Al-Antari, M.A.; Al-Masni, M.A.; Choi, M.T.; Han, S.M.; Kim, T.S. A fully integrated computer-aided diagnosis system for digital X-ray mammograms via deep learning detection, segmentation, and classification. Int. J. Med. Inform. 2018, 117, 44-54. [CrossRef] 
96. Movik, E.; Dalsbø, T.K.; Fagelund, B.C.; Friberg, E.G.; Håheim, L.L.; Skår, A. Digital Breast Tomosynthesis with Hologic 3D Mammography Selenia Dimensions System for Use in Breast Cancer Screening: A Single Technology Assessment; Knowledge Centre for the Health Services at the Norwegian Institute of Public Health (NIPH): Oslo, Norway, 2017. Available online: https://www.ncbi.nlm.nih.gov/books/NBK482099/pdf/Bookshelf_ NBK482099.pdf (accessed on 31 July 2020).

97. Liang, X.; Vacher, S.; Boulai, A.; Bernard, V.; Baulande, S.; Bohec, M.; Bièche, I.; Lerebours, F.; Callens, C. Targeted next-generation sequencing identifies clinically relevant somatic mutations in a large cohort of inflammatory breast cancer. Breast Cancer Res. 2018, 20, 88. [CrossRef] [PubMed]

98. Nagahashi, M.; Shimada, Y.; Ichikawa, H.; Kameyama, H.; Takabe, K.; Okuda, S.; Wakai, T. Next generation sequencing-based gene panel tests for the management of solid tumors. Cancer Sci. 2019, 110, 6-15. [CrossRef] [PubMed]

99. Bray, F.; Ferlay, J.; Soerjomataram, I.; Siegel, R.L.; Torre, L.A.; Jemal, A. Global cancer statistics 2018: GLOBOCAN estimates of incidence and mortality worldwide for 36 cancers in 185 countries. CA Cancer J. Clin. 2018, 68, 394-424. [CrossRef]

100. Riza, E.; Karakosta, A.; Tsiampalis, T.; Lazarou, D.; Karachaliou, A.; Ntelis, S.; Karageorgiou, V.; Psaltopoulou, T. Knowledge, Attitudes and Perceptions about Cervical Cancer Risk, Prevention and Human Papilloma Virus (HPV) in Vulnerable Women in Greece. Int. J. Environ. Res. Public Health 2020, 17, 6892. [CrossRef] [PubMed]

101. Tramuto, F.; Mazzucco, W.; Maida, C.M.; Affronti, A.; Affronti, M.; Montalto, G.; Vitale, F. Serological pattern of hepatitis B, C, and HIV infections among immigrants in sicily: Epidemiological aspects and implication on public health. J. Community Health 2012, 37, 547-553. [CrossRef]

102. Kaucher, S.; Khil, L.; Kajüter, H.; Becher, H.; Reder, M.; Kolip, P.; Spallek, J.; Winkler, V.; Berens, E.M. Breast cancer incidence and mammography screening among resettlers in Germany. BMC Public Health 2020, $20,417$. [CrossRef]

Publisher's Note: MDPI stays neutral with regard to jurisdictional claims in published maps and institutional affiliations.

(C) 2020 by the authors. Licensee MDPI, Basel, Switzerland. This article is an open access article distributed under the terms and conditions of the Creative Commons Attribution (CC BY) license (http://creativecommons.org/licenses/by/4.0/). 